\title{
Stimulation of Wnt/ $\beta$-Catenin Signaling to Improve Bone Development by Naringin via Interacting with AMPK and Akt
}

\author{
Dawei Wang ${ }^{\mathrm{a}}$ Wenpu Ma ${ }^{\mathrm{b}}$ Fu Wanga Jinlei Dong ${ }^{\mathrm{a}}$ Dan Wang ${ }^{\mathrm{c}}$ Bo Sun ${ }^{\mathrm{d}}$ \\ Bomin Wang ${ }^{a}$ \\ aDepartment of Orthopedics, Shandong Provincial Hospital Affiliated to Shandong University, Jinan \\ 'Department of Orthopedics, Liaocheng People's Hospital, Liaocheng, 'Department of Science and \\ Education, Shandong Provincial Hospital affiliated to Shandong University, Jinan, 'Department of X-ray \\ Diagnosis Research, Shandong Medical Imaging Research Institute, Jinan, China
}

\section{Key Words}

Naringin $-\beta$-catenin - Lymphoid enhancer factor (LEF)/ T-cell factor (TCF) • Protein kinase B $(\mathrm{Akt}) \cdot \mathrm{AMP}$-activated protein kinase (AMPK)

\begin{abstract}
Background/Aims: Naringin is a naturally existing compound in citrus fruits and has been elucidated to promote bone development and maintenance. Methods: The biological roles of naringin were investigated in vitro using osteoblast-like UMR-106 cells, and in vivo through performing ovariectomy to mimic osteoporosis in female mice. Since $W n t / \beta$-catenin signaling is involved in osteoblastogenesis, the effect of naringin on $\mathrm{Wnt} / \beta$-catenin signaling was studied. Results: Naringin promoted the mRNA and protein expressions of $\beta$-catenin, and improved Ser552 phosphorylation on $\beta$-catenin in UMR-106 cells, which leads to the activation of lymphoid enhancer factor (LEF)/ T-cell factor (TCF) transcription factors. The recruitments of protein kinase B (Akt) inhibitor (Akti-1/2) and AMP-activated protein kinase (AMPK) inhibitor (Dorsomorphin) reduced the influence of naringin on $\beta$-catenin phosphorylation, suggesting naringin activates $\beta$-catenin via regulating Akt and AMPK. In ovariectomized (OVX) mice naringin treatment improved the bone strength while AMPK and Akt inhibitors partly reversed the effect, which further proved the involvements of Akt and AMPK in the action of naringin in vivo. Conclusion: Our study points to a novel finding on the mechanism of naringin in facilitating bone formation via Akt and AMPK signaling.
\end{abstract}

Copyright (C) 2015 S. Karger AG, Basel

D. Wang and W. Ma have contributed equally to this work.

Bomin Wang,

KARGER 125
Department of Orthopedics, Provincial Hospital Affiliated to Shandong University, Jinan 250021 (China)

Tel. +86-53168776382, Fax +86-53168776382, E-Mail bmwang1234@163.com 


\section{Cellular Physiology Cell Physiol Biochem 2015;36:1563-1576 \begin{tabular}{l|l} 
and Biochemistry Published online: July 10, 2015 & $\begin{array}{l}\text { C) 2015 S. Karger AG, Basel } \\
\text { www.karger.com/cpb }\end{array}$ \\
\hline
\end{tabular} \\ Wang et al.: Mechanism of Naringin on Facilitating Bone Formation}

\section{Introduction}

Osteoporosis has become an epidemic problem among aging population, especially postmenopausal women [1-3]. Decreased bone mass and microarchitectural deterioration of bone tissues give rise to high risk of fractures of hip, vertebrae, pelvis and wrist, causing disability and even death $[4,5]$. However, osteoporosis is a condition characterized as bone mineral density (BMD) below $2 \bullet 5$ SD, which normally can be diagnosed and treated [6].

Development and maintenance of bones rely on the interaction between two critical cell types, osteoblasts and osteoclasts. Osteoblasts differentiated from common mesenchymal precursors are required in bone formation, which are tightly controlled by several transcription factors and affected by surrounding cells or tissues via cell-cell signaling. Wnt/ $\beta$-catenin signaling was proposed to be involved in osteoblastogenesis [7-9]. It was reported that the activation of $\mathrm{Wnt} / \beta$-catenin signaling was remarkably triggered by osteogenic inducers, and BIO induced osteogenesis activated Wnt/ $\beta$-catenin signaling even in the presence of ethanol which led to the shift of multipotential mesenchymal stem cells in bone marrow (BMSCs) from osteogenesis towards adipogenesis [10]. Wnt proteins are signaling molecules that affect cell proliferation, differentiation and survival [11]. The canonical Wnt signaling pathway employs the clustering between Wnt proteins, Frizzled (FZD), and low-density lipoprotein receptor-related protein 5/6 (LRP5/6) receptors, resulting in phosphorylation, which in turn stabilizes $\beta$-catenin through suppressing glycogen synthase kinase-3 (GSK-3) $[12,13]$. Unphosphorylated $\beta$-catenins accumulate in the nucleus and bind to lymphoid enhancer factor (LEF)/ T-cell factor (TCF) transcription factors while phosphorylated $\beta$-catenins are degraded [14]. The activation of LEF/TCF transcription factors enables the expressions of osteogenic specific genes [15]. In contrast, osteoclasts derived from granulocyte-monocyte precursors secret acid and lytic enzymes to decalcify and degrade bone matrix [16]. Enhanced osteoclast proliferation was reported after estrogen loss, suggesting a pathological mechanism of osteoporosis in postmenopausal women [17]. In addition, the lack of osteoclastogenesis inhibitory factors and overexpression of soluble osteoclast differentiation factors were documented in severe osteoporosis $[18,19]$.

Naringin is abundantly found in the pericarp (albedo, membrane and pith) of citrus fruits, especially in grapefruits $[20,21]$. Recently, it has been proposed as an active component in grapefruit juice which can promote osteoblastogenesis and abrogate osteoclastogenesis [22-24]. As an inexpensive raw material, numerous studies have been performed to investigate the potential clinical value of naringin in treating cardiovascular diseases, cancer and osteoporosis. Recently, naringin was found to protect against minimal hepatic encephalopathy via directly activating JAK2/STAT3 signaling [25]. Importantly, it was reported that naringin exerts oestrogen-like activities and significantly elevates cell proliferation, total protein content and alkaline phosphatase (ALP) activities in rat UMR-106 cells $[26,27]$. Additionally, activations of the PI3K, Akt, c-Fos/c-Jun and AP-1 pathways were found to be involved in the stimulatory effects of naringin on bone morphogenetic protein-2 (BMP-2) expression in MC3T3-E1 osteoblastic cells [28]. Most therapies such as risedronate and estrogen were designed to repress bone resorption and remodeling, whereas few therapies such as teriparatide (parathyroid hormone) are used to improve skeletal microarchitecture via activating osteoblasts [29-31]. This study aimed to investigate the influence of naringin on osteoblasts and bone development. To reveal the mechanism of naringin function, we studied the impacts of dorsomorphin blocking AMP-activated protein kinase (AMPK) and Akti-1/2 inhibiting Akt 1 and 2 along with naringin on osteoblast-like cells UMR-106 in vitro and bone development of mice in vivo.

\section{Materials and Methods}

Animals

The care and use of animals in this study followed the guidelines and protocol approved by the Institutional Animal Care and Use Committee (IACUC) of Provincial Hospital Affiliated to Shandong KARGER 


\section{Cellular Physiology Cell Physiol Biochem 2015;36:1563-1576 \begin{tabular}{l|l|l}
\hline DOI: 10.1159/000430319 & (C)15 S. Karger AG, Basel
\end{tabular} \begin{tabular}{l|l|l|l|l|l} 
and Biochemistry Published online: July 10, 2015 & www.karger.com/cpb \\
\cline { 1 - 2 }
\end{tabular} \\ Wang et al.: Mechanism of Naringin on Facilitating Bone Formation}

University. The IACUC committee members at Provincial Hospital Affiliated to Shandong University approved this study. All efforts were made to minimize the number of animals used and their suffering. Twenty four weeks old female mice were kept in a temperature $\left(21 \pm 2^{\circ} \mathrm{C}\right)$ and humidity $(55 \pm 10 \%)$ controlled room on a 12: 12 light dark cycle (light 7AM-7PM) with a normal calcium level $(0.6 \% \mathrm{Ca})$ control diet for 2 days before the treatment. Mice had ad libitum access to water and food. Five mice were sham-operated while the rest of the mice underwent ovariectomy (OVX) to induce bone loss at the age of one month. After recovering for 2 weeks, OVX mice were randomly divided into three groups: OVX vehicle (PBS), OVX naringin (5 nM) and OVX naringin with PTH. Control group is sham vehicle. Mice were pair-fed with the control diet, received treatment orally for 6 weeks according to previous study [32]. At the end of treatment, the mice were anaesthetized with $10 \%$ ketamine $(75 \mathrm{mg} / \mathrm{kg}$; Alfamedic Limited). Bone specimens from femur, tibia and lumbar spine were collected and stored at $-20^{\circ} \mathrm{C}$ until analysis.

\section{Naringin extraction and identification}

Naringin was extracted from $3.0 \mathrm{~kg}$ of DF. In brief, DF were cut and washed in $60 \%(\mathrm{v} / \mathrm{v})$ ethanol for three times and 2 hours each time. The filtrations were collected and concentrated under a reduced pressure. After adding some distilled water, DF was eluted using equal volumes of petroleum ether, ethyl acetate and n-butyl alcohol. $24.0 \mathrm{~g}$ DF extract was obtained and separated by the column chromatography ulteriorly. The gradient elution by chloroform-methanol from 100:0 to 1:1 was utilized. The eluate was further eluted by thin layer chromatography (TLC) and 7 extracts were collected (Fr. 1 to Fr. 7). Fr.5 was further filtered by ODS column chromatography under reduced pressure and SephadexLH-20 silica column chromatography. Eventually, methonal-water (v:v=1:1) was used to elute the extract. The compound (10.5 $\mathrm{mg}$ ) obtained was naringin and was then analyzed by high performance liquid chromatography (HPLC) equipped with a Waters 1525 pump, a 2707 auto sampler and a 2998 PDA detector.

Culture of rat osteoblastic UMR-106 cells

UMR-106 cells were purchased from Shanghai Tongpai Biology Company and cultured in Dulbecco's modified Eagle's medium (DMEM) supplemented with 10\% fetal bovine serum (FBS), penicillin $100 \mathrm{U} / \mathrm{ml}$ and streptomycin $100 \mathrm{mg} / \mathrm{ml}$ at $37^{\circ} \mathrm{C}$ at a density of $3.5 \times 10^{3}, 2.5 \times 10^{4}$ and $5 \times 10^{4}$ cells per well in 96 -well, 24well or 6-well plates respectively for different assays. After $48 \mathrm{~h}$, the medium was changed to phenol-red free DMEM supplemented with 1\% dextran-charcoal-stripped serum (sFBS) for $24 \mathrm{~h}$. Different concentrations of naringin $(0,0.5,1,5,10$ and $20 \mathrm{nM})$ were examed to determine a concentration exerting maximum effects on cell proliferation. For the assessments of the mRNA and protein expressions of $\beta$-catenin, cells were treated by vehicle (PBS) as control, Wnt3a (10 ng/ml), Dkk1 (100 ng/ml), naringin (10 nM), naringin (10 $\mathrm{nM})+\operatorname{Dkk} 1(100 \mathrm{ng} / \mathrm{ml})$ and naringin $(10 \mathrm{nM})+$ FH535 $(10 \mu \mathrm{M})$. When indicated, cells were divided into four groups treated by control, naringin $(10 \mathrm{nM})$, naringin $(10 \mathrm{nM})+$ dorsomorphin $(100 \mathrm{nM})$, and naringin $(10 \mathrm{nM})+$ Akti-1/2 (200 nM), respectively.

\section{Isolation of Nuclei and Cytosol}

Nuclei and cytosol were isolated using a nuclear extract kit (NE-PER Nuclear and Cytoplasmic Extraction Reagents, 78833, Pierce) according to the manufacturer's instructions. Briefly, cells were harvested with trypsin-EDTA and span down at $500 \times \mathrm{g}$ for $5 \mathrm{~min}$. Then CER I and CER II were added on ice subsequently with necessary centrifugation, followed by spinning down to collect the cytoplasmic extracts. The pellets were resolved in NER solution and collected. All samples were stored in $-80^{\circ} \mathrm{C}$ until use.

\section{Cell proliferation assay}

The cell proliferation rate employed a BrdU incorporation assay. After distinctive treatments, BrdU $(10 \mathrm{ng} / \mathrm{ml})$ was added to the media. Then the cells were incubated for $4 \mathrm{~h}$ and washed. Cells were fixated and then stained with the BrdU antibody by using a BrdU staining kit (Roche Applied Sciences, Branford, CT, USA) following the manufacturer's instruction. O.D. (Optical Density) has measured at $450 \mathrm{nM}$.

Real-time quantitative reverse transcriptase-polymerase chain reaction (RT-PCR) analysis

Total RNA from cells were extracted by RNeasy Mini Kit (Qiagen). Quality and quantity of RNA were measured by NanoDrop 8000 spectrophotometer (Thermo Scientific). 1000 ng RNA was used for each reaction to produce cDNA using high capacity cDNA reverse transcription kit (Applied Biosystems) 


\section{Cellular Physiology Cell Physiol Biochem 2015;36:1563-1576 \begin{tabular}{l|l|l} 
DOI: 10.1159/000430319 & (C) 2015 S. Karger AG, Basel
\end{tabular} \begin{tabular}{l|l|l|l|l|l} 
and Biochemistry Published online: July 10, 2015 & www.karger.com/cpb \\
\cline { 1 - 2 }
\end{tabular} \\ Wang et al.: Mechanism of Naringin on Facilitating Bone Formation}

following manufacturer's instructions. The reaction was initiated at $25^{\circ} \mathrm{C}$ for $5 \mathrm{~min}$, annealed at $50^{\circ} \mathrm{C}$ and elongated at $70^{\circ} \mathrm{C}$. cDNA products were diluted by adding RNase and DNase free water till $250 \mu \mathrm{l}$ and frozen at $-20^{\circ} \mathrm{C}$ before gene expression assay. Each PCR reaction mixture contained $10 \mu \mathrm{l} 1 \times \mathrm{PCR}$ master mix, $5 \mu \mathrm{l}$ diluted cDNA, $4 \mu \mathrm{l}$ water and $1 \mu \mathrm{l}$ probe. Gene expression was measured with quantitative real-time RTPCR system. The primers are: for GAPDH, 5`-ACATTTTGCTGATGACTG G-3` and 5`TGAATGGTAGGAGCTTGA CT-3`; for $\beta$-catenin, 5`-ATATTGACGGGC AGTATGCA-3` and 5`-TCAAACTGCGTGGATGGGAT-3`; for COL1, 5`-ACATGC CGTGACTTGAGACTCA-3` and 5`-GCCAGACGTGTTTCTTGTCCTT-3`; for ALP, 5'-ACGAGCTGAACAGGAACAACGT-3` and 5'-CACCAGCAAGAAGAAGCC TTTG-3`; for Runx2, 5`TGAGCTGAGAGGGCATATGGCC-3` and 5`TAGACA CCA AACTCCACA GCCC-3`.

\section{Western blot analysis}

The $\beta$-catenin ( 92 kDa) expressed was determined by Western blot. Cells were harvested and lysed with lysis buffer (RIPA, Abcam). Each sample was added into $20 \mu \mathrm{l} 2 \times$ sample loading buffer $(0.125 \mathrm{M}$ of $5 \mathrm{M}$ Tris- $\mathrm{HCl}$, amresco; $20 \%$ glycerol, usb; $4 \%$ of $10 \%$ sodium dodecyl sulfate, amresco; $1 \%$-mercaptoethanol, amresco; $0.2 \%$ of $0.05 \%(\mathrm{w} / \mathrm{v}$ ) bromophenol blue, sigma). Actin was used as a control. The samples were boiled for $5 \mathrm{~min}$ before loading. 10\% running gel (25\% of $40 \%$ acrylamide stock, Beyotime; $0.375 \mathrm{M}$ of $1.5 \mathrm{M}$ Tris- $\mathrm{HCl}, \mathrm{pH} 8.8 ; 1 \%$ of $10 \%$ sodium dodecyl sulfate; $1 \%$ of $10 \%$ ammonium persulfate; $0.1 \%$ Tetramethylethylenediamine) was utilized. The gel was transferred to a same size membrane (Nitrocellulose transfer membrane, Protian) within transfer buffer (25 mM Tris base, $192 \mathrm{mM}$ glycine, 0.037\% sodium dodecyl sulfate, and $20 \%$ methanol) under $45 \mathrm{~V}$ for $40 \mathrm{~min}$. The membrane were then incubated in $1 \mathrm{st}$ antibody [Phospho- $\beta$-Catenin (Ser552) Antibody \#9566, CST; $\beta$-Catenin Antibody \#9581, CST; $\beta$-Actin Antibody sc-47778, Santa Cruz] with a 1/1000 dilution in blocking buffer (50 mM Tris base; $100 \mathrm{mM} \mathrm{NaCl}$; $0.02 \%$ Tween 20 ; and 3\% BSA) overnight. The membrane was washed by TTBS $(0.1 \%$ Tween $20,10 \mathrm{mM}$ Tris base, $100 \mathrm{mM} \mathrm{NaCl}$, pH 7.5) for three times before adding secondary antibody (ab6721, Abcam) with $1 / 5000$ dilution in blocking buffer for 2 hours. Background color was reduced carefully by washing with TTBS. The results were visualized using ECL kit (Abcam) and observed by GeneGnome mechine (Syngene).

\section{Transient transfection and ER-mediuated luciferase activity assay}

Cells were transfected by Lipofectamine ${ }^{\mathrm{TM}} 2000$ reagent. Lipofectamine 2000 was incubated in Dulbecco's Modified Eagle Medium for $5 \mathrm{~min}$. Then it was incubated with diluted ER- $\alpha$, ER- $\beta$ and EREcontaining luciferase reporter plasmid vERETkluc for $20 \mathrm{~min}$ before adding into Dulbecco's Modified Eagle Medium with 10\% fetal bovine serum. Also, $0.4 \mathrm{mg}$ per well ER-a or ER-b plasmid, $0.4 \mathrm{mg}$ per well vERETkluc, together with $0.1 \mathrm{mg}$ per well internal control reporter plasmid pRL-TK, a Renilla luciferase control vector, were co-transfected into the cells in duplicate. After overnight transfection, the cells were treated with vehicle, naringin (10 nM) or naringin with Dkk1 (100 ng/ml) for $24 \mathrm{~h}$. After treatment, the cells were lysed with lysis buffer and luciferase activity was measured using Dual Luciferase. Reporter Assay System (Promega Corporation) and the signal were detected by TD-20/20 Luminometer (Turner Design, Sunnyvale, USA).

Alkaline phosphatase assay

ALP activity was measured directly on the monolayer of cell cultures on a ninety-six-well microplate after treatments with vehicle, naringin or PTH. The assay was carried out by incubating the cells with $10 \mathrm{mM}$-p-nitrophenylphosphate for $30 \mathrm{~min}$ at $37^{\circ} \mathrm{C}$. The absorbance of color change was measured at 405 $\mathrm{nm}$ in a microplate reader. A Bradford protein assay was carried out to normalize ALP expression and as ALP activity was expressed U/l per mg protein.

Assessment of bone properties by peripheral quantitative computed tomography ( $p Q C T$ )

Bone mineral density (BMD), cross-sectional area and stress-strain index (SSI) in the distal femur, proximal tibia and lumbar spine region L1 were measured using a StraTecXCT2000 machine (Norland Stratec Medizintechnik, GmbH, Birkenfeld, Germany). Mid-shaft and distal/proximal regions of femur and tibia were scanned. The distal/proximal site was defined as $2.5 \mathrm{~mm}$ away from femur/tibia head. The midshaft was the middle region of each long bone. All scans were performed using the protocol designed for studying isolated small bones [33].

\section{KARGER}




\section{Cellular Physiology Cell Physiol Biochem 2015;36:1563-1576

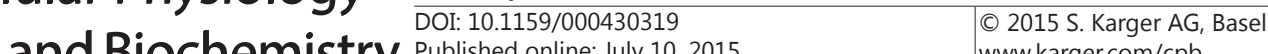 \begin{tabular}{l|l|} 
and Biochemistry Published online: July 10, 2015 & www.karger.com/cpb \\
\cline { 1 - 2 }
\end{tabular} \\ Wang et al.: Mechanism of Naringin on Facilitating Bone Formation}

\section{Bone stiffness measures}

Bone stiffness was measured using a specified 3-point bending test [34]. The anterior side, which was the point receiving compression, was placed upwards. Known loads were applied on the middle of femur, tibia or lumbar spine until fracture occurred. All the specimens were pressed at a displacement of $5 \mathrm{~mm} /$ min, and a load-deformation curve was plotted simultaneously. Bone stiffness was determined from the load-deformation curve.

\section{Statistical analysis}

All values are expressed as means \pm standard deviation. The in vivo data were analyzed using one-way ANOVA followed by Tukey's post-test and the in vitro data were analyzed by the non-paired Student's t test between different groups using the GraphPad PRISMw software package (GraphPad Software, Inc.). $\mathrm{P}<0.05$ were considered as significant.

\section{Results}

Naringin enhanced Wnt/ $\beta$-catenin signaling pathway

We first examined the effects of different concentrations of naringin on UMR-106 cell proliferation. With the increasing concentration of naringin from $0.5 \mathrm{nM}$ to $10 \mathrm{nM}$, cell proliferation was significantly accelerated (Fig. 1A). A further increase of naringin concentration to $20 \mathrm{nM}$ did not lead to obvious change in cell proliferation compared to 10 $\mathrm{nM}$. Therefore, $10 \mathrm{nM}$ was employed as the optimal dosage in further investigation on the functions of naringin in Wnt/ $\beta$-catenin signaling pathway.

To investigate the influences of naringin on $\beta$-catenin regulation, UMR-106 cells were divided into six groups: control, Wnt3a, DKK1, 10nM naringin, Dkk1+naringin and FH535+naringin respectively, and the mRNA level of $\beta$-catenin in each group was measured. The results showed a striking increase in the mRNA level of $\beta$-catenin $(p<0.001)$ by Wnt3a treatment(Fig. 1B). In contrast, DKK1 significantly reduced mRNAlevel of $\beta$-catenin $(\mathrm{p}<0.001)$, due to its inhibitory role in Wnt signaling pathway. Naringin treatment significantly elevated the mRNA level of $\beta$-catenin $(p<0.01)$ compared to the control group. DKK1+naringin and FH535+naringin treatments significantly reduced mRNA levels of $\beta$-catenin compared to control group (DKK1+naringin, $\mathrm{p}<0.05$; FH535+naringin, $\mathrm{p}<0.01$ ). In comparison with naringin treatment, DKK1+naringin and FH535+naringin consistently inhibited the mRNA levels of $\beta$-catenin (DKK1+naringin, $p<0.01$; FH535+naringin, $p<0.001$ ).

To further confirm the effect of naringin on $\beta$-catenin regulation, we next examined the protein expression levels of $\beta$-catenin in each group using western blot analysis. The relative expression was normalized to $\beta$-actin and is illustrated in Fig. 1D. As expected, Wnt3a dramatically elevated the protein expression of $\beta$-catenin $(\mathrm{p}<0.001)$ whereas DKK1 led to a significant decrease in the protein level of $\beta$-catenin $(\mathrm{p}<0.01)$. In addition, naringin treatment markedly promoted the protein expression of $\beta$-catenin $(p<0.01)$. It was also observed that DKK1+naringin and FH535+naringin treatments significantly reduced the protein expressions of $\beta$-catenin compared to control group (DKK1+naringin, $\mathrm{p}<0.05$; FH535+naringin, $\mathrm{p}<0.05$ ) or naringin treatment group (DKK1+naringin, $\mathrm{p}<0.01$; FH535+naringin, $\mathrm{p}<0.01$ ). Taken together these results were consistent with the results of the mRNA levels of $\beta$-catenin in each group, which clearly demonstrated that naringin treatment enhanced $\mathrm{Wnt} / \beta$-catenin signaling pathway.

\section{Phosphorylation of $\beta$-catenin by naringin via AMPK and Akt signaling}

There have been numerous reports showing that phosphorylation could greatly affect the expression and localization of $\beta$-catenin. By screening, we found that the phosphorylation on residue S552 was enhanced upon Naringin application. Therefore, we then investigated the protein expressions of phospho- $\beta$-catenin in UMR-106 cells treated by control, $10 \mathrm{nM}$ naringin, $10 \mathrm{nM}$ naringin+100 nM dorsomorphin, and $10 \mathrm{nM}$ naringin+200 nM Akti-1/2, using phospho- $\beta$-catenin (Ser552) antibody. Fig. 2A shows the results of 

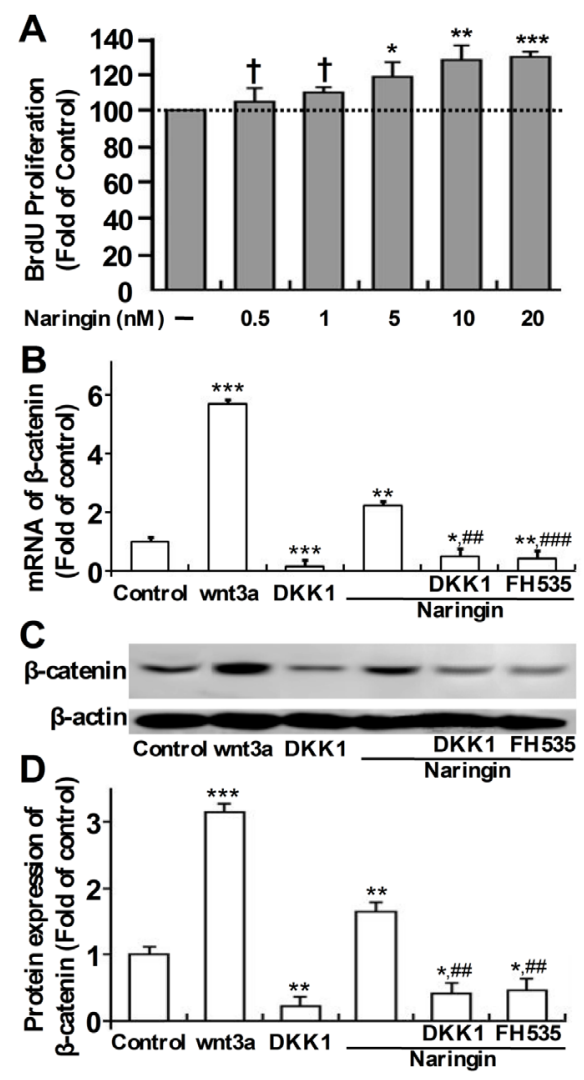

Fig. 1. Naringin stimulates cell proliferation by increasing mRNA and protein expression of $\beta$-catenin in vitro. (A) Effect of naringin on osteoblastic UMR-106 cells of different naringin concentration using BrdU incorporation cell proliferation assay. Values were normalized with the control and represent mean \pm SEM $(\mathrm{n}=3) .{ }^{*}, \mathrm{P}<0.05 ;{ }^{* *}, \mathrm{P}<0.01$; ***, $\mathrm{P}<0.001$; $\dagger$, not significant compared with control. (B) mRNA level of $\beta$-catenin under various treatment. (C) Representative western blot on the expression of $\beta$-catenin. $\beta$-actin serves as a positive control. (D) The summary of $(\mathrm{C})(\mathrm{n}=4) .{ }^{*}, \mathrm{P}<0.05$; **, $\mathrm{P}<0.01$; $* * *, \mathrm{P}<0.001$ compared with the control group, while \#\#, $\mathrm{P}<0.01$ compared with the naringin group.

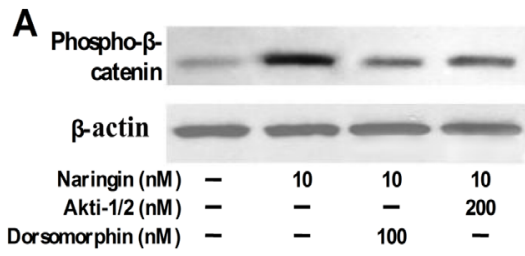

B

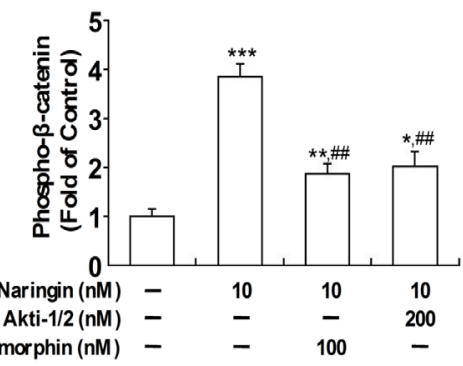

C

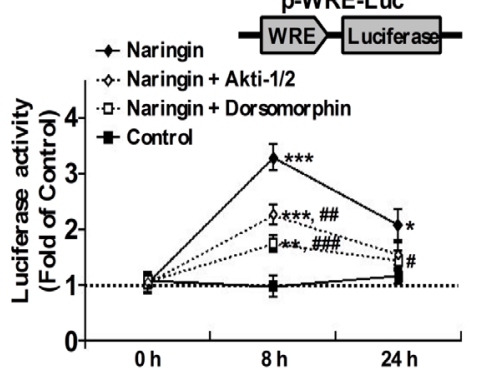

Fig. 2. AMPK and Akt phosphorylated $\beta$-catenin and increased its transcriptional activity during naringin treatment in vitro. (A) AMPK and Akt phosphorylated $\beta$-catenin during naringin treatment in osteoblastic UMR-106 cells. (B) Summary of (A) $(n=3) .{ }^{*}, \mathrm{P}<0.05$; **, $\mathrm{P}<0.01$; *** $\mathrm{P}<0.001$ compared with the control group, while \#\#, $\mathrm{P}<0.01$ compared with the naringin group. (C) Effects of naringin and inhibitors of AMPK and Akt on $\beta$-catenin signaling pathway were tested using reporter construct P-WRE-Luc. Cells were transfected with construct for $24 \mathrm{~h}$ and treated with $10 \mathrm{nM}$ naringin for 2 hours then washed with PBS and replaced with growth medium with indicated inhibitors. Cell lysates were collected and luciferase activity was measured at 0,8 and 24 hours after naringin treatment. All data were normalized with the value of each $0 h$. Data represent mean \pm SEM. $(n=3)$; *, $\mathrm{P}<0.05$; **, $\mathrm{P}<0.01$; ***, $\mathrm{P}<0.001$ compared with the control group, while \#, $\mathrm{P}<0.05$; \#\#, $\mathrm{P}<0.01$; \#\#\#, $\mathrm{P}<0.001$ compared with the naringin group.

western blot and Fig. 2B illustrated the relative expression levels of phospho- $\beta$-catenin in each group. Naringin significantly increased Ser552 phosphorylation of $\beta$-catenin $(p<0.001)$ compared to control group (Fig. 2B). Importantly, the additions of Akti-1/2 or dorsomorphin reduced the Ser552 phosphorylation on $\beta$-catenin (naringin + Akti-1/2, $<<0.01$; naringin 
Fig. 3. The nuclear localization of $\beta$-catenin was affected by its phosphorylation. (A) immunofluorescence images of osteoblastic UMR-106 cells demonstrated the nuclear localization of $\beta$-catenin. Yellow arrows indicate the cytosolic $\beta$-catenin while blue arrows indicate the nuclear localized $\beta$-catenin. (B) Western blot analysis of nuclear and cytoplasm localization of $\beta$-catenin. (C) Summary of (B) $(n=4)$. ${ }^{* *}, \mathrm{P}<0.01$; ${ }^{* *}, \mathrm{P}<0.001$ compared with the control group, while \#, $\mathrm{P}<0.05$; \#\#, $\mathrm{P}<0.01$ compared with the naringin group.

+ dorsomorphin, $\mathrm{p}<0.01$ ). Compared to control, naringin + Akti-1/2 and naringin + dorsomorphin significantly induced Ser552 phosphorylation on $\beta$-catenin (naringin + dorsomorphin, $\mathrm{p}<0.01$; naringin + Akti$1 / 2, p<0.05$ ). These results indicated that naringin interacted with AMPK and Akt to induce Ser552 phosphorylation of $\beta$-catenin. To further investigate whether the Ser552 phosphorylation could influence the transcriptional activity of LEF/TCF in UMR106 cells, we transfected UMR-106 cells with a luciferase reporter inserted downstream of Wnt-responsive element (WRE), a short element in LEF-1 promoter. As shown in Fig. 2C, the LEF/TCF transcriptional activity in UMR-106 cells was significantly improved within 8 hours after naringin treatment

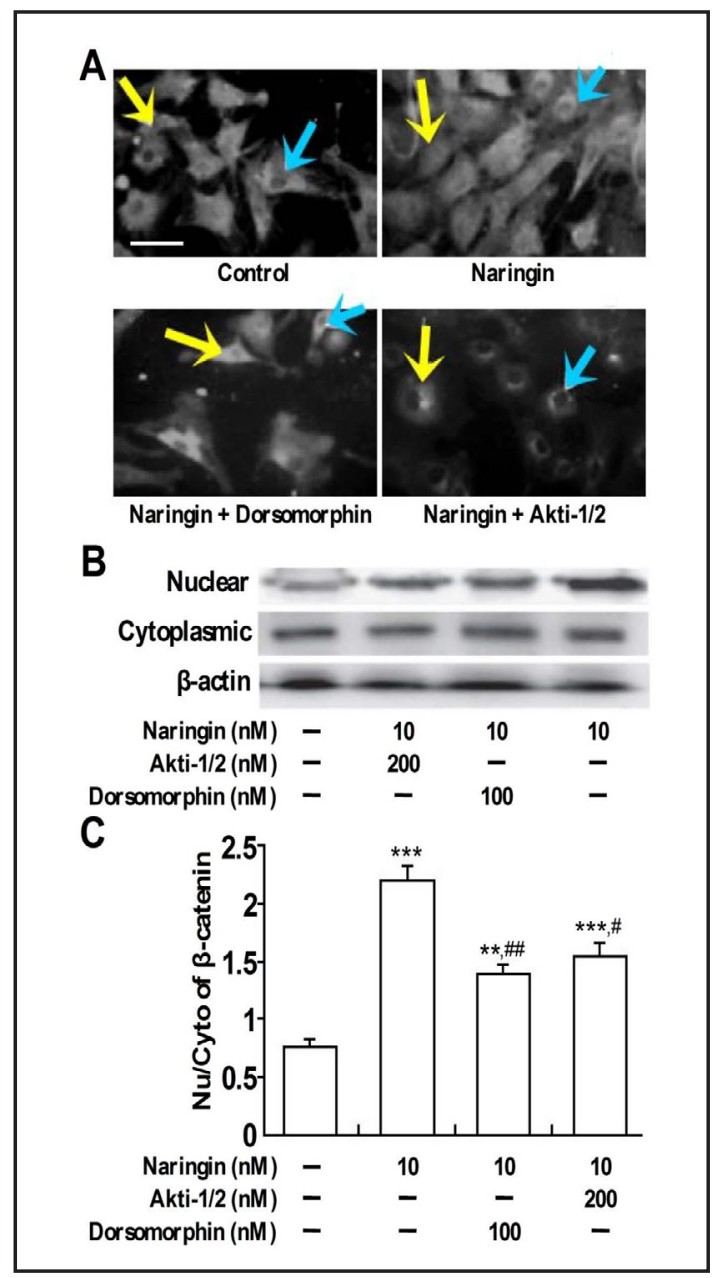
$(p<0.001)$, naringin + dorsomorphin treatment $(p<0.001)$ and naringin + Akti- $1 / 2$ treatment $(\mathrm{p}<0.01)$, compared with control. This result clearly indicates the LEF/TCF transcriptional activity was repressed by additions of Akti-1/2 $(p<0.01)$ or dorsomorphin $(p<0.001)$ compared with naringin treatment alone. It would be interesting to point out that 24 hours after naringin treatment, the increase in the transcriptional activity was attenuated to about half of that of 8 hours, reflecting the half-life of naringin-induced activation of the $\beta$-catenin pathway.

\section{Naringin stimulated $\beta$-catenin translocation}

To unambiguously reveal whether the Ser 552 phosphorylation of $\beta$-catenin by naringin leads to the activation of $\beta$-catenin, we next examined the translocation of $\beta$-catenin from cytoplasm into the nucleus in UMR-106 cells treated by Akti-1/2 or dorsomorphin in the presence or absence of naringin. We found that UMR-106 cells with naringin treatment displayed $\beta$-catenin accumulation in cell nucleus (Fig. 3A), and this finding was further confirmed by western blot results. Indeed, naringin treatment induced translocation of $\beta$-catenin, accounting for the increased relative expression of $\beta$-catenin $(p<0.001)$ in the nucleus of UMP-106 cells treated by $10 \mathrm{nM}$ naringin compared to its expression in the nucleus of control cells (Fig. 3B and C). $\beta$-catenin translocation was repressed when Akti$1 / 2$ or dorsomorphin was applied together with naringin, suggesting that naringin could participate in the regulations of AMPK or Akt signaling to regulate the activation of $\beta$-catenin. Additionally, the repression did not compensate the effects of naringin on the nuclear accumulation of $\beta$-catenin in UMP-106 cells, since significantly higher levels of $\beta$-catenin were found in cells treated by naringin + Akti- $1 / 2(\mathrm{p}<0.001)$ or naringin + dorsomorphin $(\mathrm{p}<0.01)$ 
Fig. 4. (A) In vivo dose determination of naringin. Naringin stimulates osteoblastic gene expression at $1 \mathrm{mg} / \mathrm{kg} /$ day and $5 \mathrm{mg} / \mathrm{kg} /$ day doses. (n=5 each) *, $\mathrm{P}<0.05$; **, $\mathrm{P}<0.01$; ***, $\mathrm{P}<0.001$ compared with the control group. (a) Naringin stimulates osteoblast proliferation and early differentiation assessed by ALP activity. Values represent mean \pm SEM $(n=5)$. (c) Effect of Naringin on osteoblast cell proliferation of various treatment groups using BrdU incorporation cell proliferation assay. Values represent mean \pm SEM (n=3). *, $\mathrm{P}<0.05$; **, $\mathrm{P}<0.001$; †, not significant compared with the sham group, while \#, $\mathrm{P}<0.05$; \#\#, $\mathrm{P}<0.01$ compared with the OVx group.

than control group. Altogether, these results confirmed that naringin was able to affect the regulation of $\beta$-catenin through interacting with AMPK and Akt signaling pathways.

\section{Naringin facilitated bone development in mice}

Next we measured the effects of naringin on bone development in an in vivo mouse model. The mRNA levels of ALP, Runx2 and COL1 were assessed under increasing dosage of naringin, at $0,0.5,1,5$ and $10 \mathrm{mg} / \mathrm{Kg} /$ Day respectively, to determine the optimal dosage of naringin treatment in vivo. Since the mice

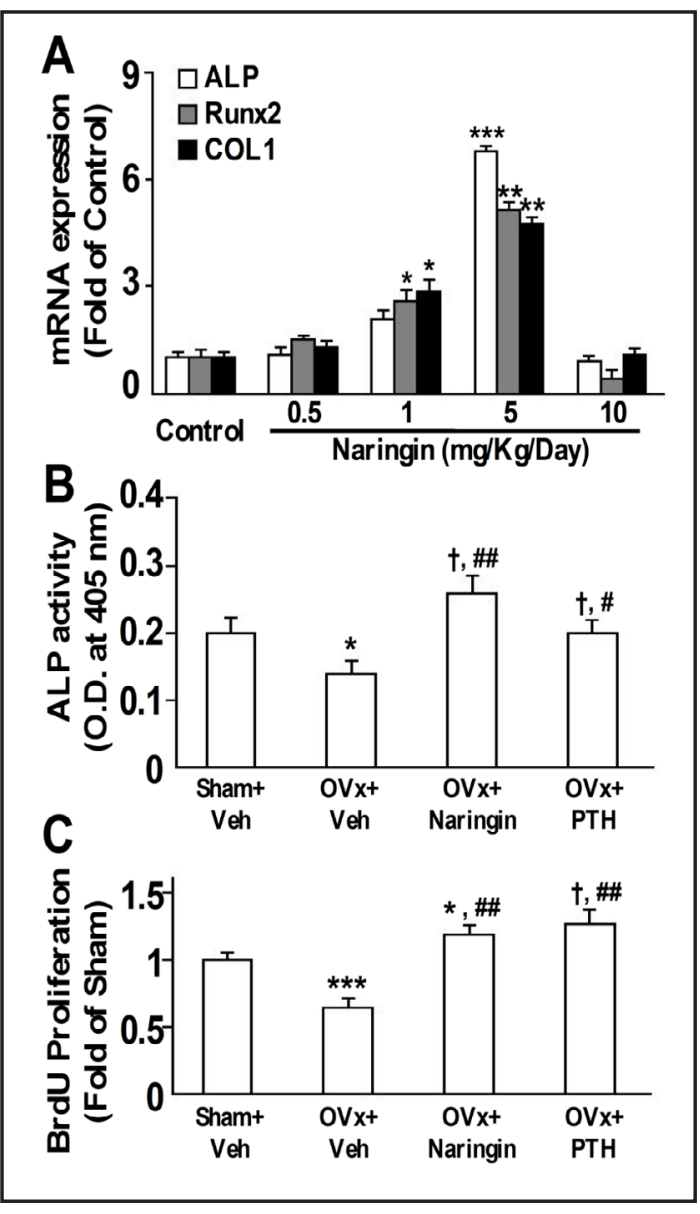

under $5 \mathrm{mg} / \mathrm{Kg} /$ Day naringin treatment exhibited the maximum levels of ALP, Runx2 and COL1 mRNA expression, this dose was utilized in further experiments of this study (Fig. 4A).

Mice were sham-operated as control or underwent OVX to induce bone loss. After 2 weeks recovery, OVX mice were randomly divided into three groups, OVX vehicle, OVX naringin and OVX parathyroid hormone (PTH). We found the ALP activity was significantly decreased in OVX vehicle mice compared to sham vehicle mice $(\mathrm{p}<0.05)$, whereas naringin and PTH treatment significantly recovered ALP activation in OVX mice (Fig. 4B). Moreover, BrdU was used to detect proliferating cells in sham and OVX mice. OVX led to a significantly reduction of cell proliferation compared to sham mice ( $\mathrm{p}<0.001)$ (Fig. 4C). OVX mice treated by naringin or PTH showed significantly increased proliferating cells compared to OVX vehicle mice. These results indicate that naringin exerts protective function on bone development.

We continued to investigate whether naringin could alter BMD, cross-section area, SSI and bone stiffness. Table 1 summarizes the effects of various treatments for 6 weeks on BMD, cross-sectional area and SSI of three regions, namely distal femur, proximal tibia and lumbar spine L-1 respectively, in the sham and OVX mice. Compared to sham mice, OVX dramatically decreased the total and trabecular BMD in the distal femur, proximal tibia and lumbar spine $\mathrm{L}-1$ regions, indicating OVX can be used as a mimic of osteoporosis. $5 \mathrm{mg} / \mathrm{Kg} /$ Day treatment of naringin on OVX mice strikingly improved both total and trabecular BMD at all of the regions compared to OVX mice. However, dorsomorphin and Akti-1/2 treatments diminished the effects of naringin on total and trabecular BMD. OVX mice also showed decreased total and trabecular cross-sectional areas at all of the three sites compared to sham mice, whereas $5 \mathrm{mg} / \mathrm{Kg} /$ Day naringin significantly reversed these decreases. Dorsomorphin treatment on OVX mice treated by naringin significantly reduced total cross-sectional area at distal femur 
Table 1. Effects of various treatment groups for 6 weeks on different bone parameters of ovariectomised (OVX) mice. ( $\mathrm{n}=8$ for each) *, $\mathrm{P}<0.05$ compared with Sham group; \#, $\mathrm{P}<0.05$ compared with OVx group; $\mathrm{a}, \mathrm{b}$ and $c$ represent $P<0.05,0.01$ and 0.001 , respectively, compared with Naringin group

\begin{tabular}{|c|c|c|c|c|c|c|c|c|c|c|c|}
\hline & & \multicolumn{2}{|c|}{ Sham (veh) } & \multicolumn{2}{|c|}{ OVX (veh) } & \multicolumn{2}{|c|}{$\mathrm{OVX}+$ Narigin } & \multicolumn{2}{|c|}{$\begin{array}{c}\text { OVX } \\
+ \text { Narigin+Dorsomorphin }\end{array}$} & \multicolumn{2}{|c|}{$\begin{array}{c}\text { OVX }+ \text { Narigin }+ \text { Akti } \\
1 / 2\end{array}$} \\
\hline & & Mean & SEM & Mean & SEM & Mean & SEM & Mean & SEM & Mean & SEM \\
\hline \multirow{3}{*}{$\begin{array}{l}\text { Total BMD } \\
\left(\mathrm{mg} / \mathrm{cm}^{3}\right)\end{array}$} & Distal femur & 397.2 & 8.2 & $333.8^{*}$ & 6.2 & $393.7^{\#}$ & 5.3 & $354.3^{*} \mathrm{~b}^{*}$ & 4.8 & $371.7 \#_{a}$ & 5.8 \\
\hline & Proximal tibia & 282.9 & 7.2 & $245.7^{*}$ & 4 & $301.4^{\#}$ & 3.8 & $249.3{ }^{*}$ & 7.9 & $273.4^{*} \mathrm{~b}$ & 4.3 \\
\hline & Lumbar spine L-1 & 236.2 & 3.5 & $218.4^{*}$ & 4.7 & $242.6^{\#}$ & 4.8 & $242.1^{\#}$ & 5.5 & $238.6^{\#}$ & 3.9 \\
\hline \multirow{3}{*}{$\begin{array}{l}\text { Trabecular } \\
\text { BMD } \\
\left(\mathrm{mg} / \mathrm{cm}^{3}\right)\end{array}$} & Distal femur & 400.4 & 3.9 & $340.1^{*}$ & 7.8 & $408.1^{\#}$ & 6.9 & $359.4^{*} \mathrm{~b}$ & 3.4 & $353.9 *_{\mathrm{b}}$ & 5.6 \\
\hline & Proximal tibia & 280.1 & 8.2 & $239.7 *$ & 6.8 & $318^{*, \#}$ & 5.8 & $254.7 *_{\mathrm{c}}$ & 3.7 & $287.3^{\#_{a}}$ & 8.3 \\
\hline & Lumbar spine L-1 & 242.5 & 3.9 & $221.6^{*}$ & 7.1 & $248.1^{\#}$ & 3.3 & 240.5 & 3.8 & 237.8 & 5.9 \\
\hline \multirow{3}{*}{$\begin{array}{l}\text { Total cross- } \\
\text { sectional } \\
\text { area }\left(\mathrm{mm}^{2}\right)\end{array}$} & Distal femur & 4.1 & 0.29 & 3.41 & 0.15 & $4.41^{\#}$ & 0.19 & $3.68 \mathrm{a}$ & 0.12 & 3.84 & 0.14 \\
\hline & Proximal tibia & 4.15 & 0.42 & $2.77^{*}$ & 0.3 & $5.16^{\#}$ & 0.26 & $3.52 \mathrm{a}$ & 0.39 & $4.67 \#$ & 0.27 \\
\hline & Lumbar spine L-1 & 3.07 & 0.35 & 2.09 & 0.46 & $4.18^{*, \#}$ & 0.14 & $4.3^{*, \#}$ & 0.22 & $3.57 \#$ & 0.33 \\
\hline \multirow{3}{*}{$\begin{array}{l}\text { Trabecular } \\
\text { cross- } \\
\text { sectional } \\
\text { area }\left(\mathrm{mm}^{2}\right)\end{array}$} & Distal femur & 1.81 & 0.15 & 1.3 & 0.18 & 1.81 & 0.16 & 1.38 & 0.24 & 1.45 & 0.17 \\
\hline & Proximal tibia & 1.92 & 0.21 & $1.01^{*}$ & 0.11 & $2.34^{\#}$ & 0.12 & $1.22 * \mathrm{~b}$ & 0.17 & $1.87^{\#} \mathrm{a}$ & 0 \\
\hline & Lumbar spine L-1 & 1.38 & 0.31 & 0.79 & 0.15 & $1.53^{\#}$ & 0.2 & $1.36^{\#}$ & 0.12 & $1.42^{\#}$ & 0.15 \\
\hline \multirow{3}{*}{ SSI } & Distal femur & 0.742 & 0.028 & $0.371^{*}$ & 0.046 & $0.759 \#$ & 0.028 & $0.428 *_{\mathrm{b}}$ & 0.052 & $0.645^{\#}$ & 0.037 \\
\hline & Proximal tibia & 0.413 & 0.053 & $0.21^{*}$ & 0.039 & $0.547 \#$ & 0.038 & $0.313 b$ & 0.019 & $0.368^{\#}{ }_{a}$ & 0.029 \\
\hline & Lumbar spine L-1 & 0.571 & 0.038 & $0.412^{*}$ & 0.043 & $0.701^{*, \#}$ & 0.029 & $0.688^{*}, \#$ & 0.022 & $0.699 \#$ & 0.045 \\
\hline
\end{tabular}

Table 2. Effects of various treatment groups on biomechanical bone strength in ovariectomised (OVX) mice. $(\mathrm{n}=8$ each) *, $\mathrm{P}<0.05$ compared with Sham group; \#, $\mathrm{P}<0.05$ compared with OVx group; $\mathrm{a}, \mathrm{b}$ and $\mathrm{c}$ represent $\mathrm{P}<0.05,0.01$ and 0.001 , respectively, compared with Naringin group

\begin{tabular}{|c|c|c|c|c|c|c|c|c|c|c|}
\hline & \multicolumn{2}{|c|}{ Sham (veh) } & \multicolumn{2}{|c|}{ OVX (veh) } & \multicolumn{2}{|c|}{ OVX+ Narigin } & \multicolumn{2}{|c|}{$\begin{array}{c}\text { OVX } \\
+ \text { Narigin+Dorsomorphin }\end{array}$} & \multicolumn{2}{|c|}{$\begin{array}{c}\text { OVX } \\
+ \text { Narigin+Akti- } \\
1 / 2\end{array}$} \\
\hline & Mean & SEM & Mean & SEM & Mean & SEM & Mean & SEM & Mean & SEM \\
\hline Distal femur & 70.1 & 9.6 & $19.0^{*}$ & 2.7 & $65.9 \#$ & 7.7 & $29.4 *_{b}$ & 3.2 & $35.4^{*}{ }_{a, \#}$ & 4.1 \\
\hline Proximal tibia & 27.3 & 3.9 & $12.5^{*}$ & 2.1 & $23.9^{\#}$ & 2.8 & $16.5_{a}$ & 1.7 & $19.3{ }_{\mathrm{a}}$ & 1.6 \\
\hline Lumbar spine L-1 & 301.8 & 29.2 & $138.2^{*}$ & 3.0 & $279.1^{*, \#}$ & 3.4 & $208.4^{*}{ }^{\prime} \#$ & 4.0 & $231.0^{*, \#}$ & 3.1 \\
\hline
\end{tabular}

and proximal tibia, as well as trabecular cross-sectional area at proximal tibia, compared to naringin treatment on OVX mice. Only trabecular cross-sectional area at proximal tibia was significantly decreased in OVX mice treated by naringin and Akti-1/2, compared to that of OVX mice treated by naringin. SSI, referring to bone strength determined by pQCT, was significantly weakened by OVX at the three sites compared to sham mice, while naringin treatment markedly improved SSI in OVX mice. Dorsomorphin had a significant negative influence on SSI at distal femur and proximal tibia, while Akti-1/2 significantly reduced SSI at proximal tibia compared to naringin treatment on OVX mice. These above results demonstrated the positive influence of naringin on bone development and confirmed the involvement of naringin in AMPK and Akt signaling in vivo.

Bone stiffness was also measured in distal femur, proximal tibia and lumbar spine L-1 in the sham and OVX mice, which are summarized in Table 2. OVX diminished bone stiffness at all of the three regions tested. Naringin recovered the bone stiffness loss in OVX mice. The relevance between naringin and AMPK and Akt signaling was further supported by the reductions of bone stiffness by dorsomorphin or Akti-1/2 treatments on OVX mice treated by naringin.

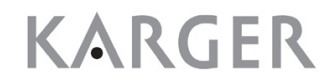




\section{Discussion}

Functions of naringin in bone development are largely unknown. In this study, we evaluated the osteoprotective effects and proposed the relationship between naringin functions and AMPK and Akt signaling using both in vitro and in vivo approaches. We demonstrated that naringin treatment had a positive influence on the Wnt/ $\beta$-catenin signaling by enhancing both transcriptional and translational levels of $\beta$-catenin. In addition, $\beta$-catenin was phosphorylated on Ser552 residue by naringin, while AMPK and Akt were shown to be involved in this process. The Ser552 phosphorylation by naringin affects $\beta$-catenin translocation to the nucleus of UMR-106 cells, which was repressed by blocking AMPK and Akt signaling. These findings were further confirmed in vivo that naringin improved bone development in OVX mice, whereas dorsomorphin and Akti-1/2 treatments diminished the effects of naringin. Taken together, these results demonstrate that naringin exerts a protective function on bone development via interacting with AMPK and Akt signaling.

Wnt/ $\beta$-catenin signaling pathway has been demonstrated as a clinical target for treatment of osteoporosis. Wht signaling regulates bone formation by stimulating the development of osteoblasts. Activation of Wnt leads to its binding with a dual receptor composed of LRP5/6 and FZD receptors, resulting in the inactivation of GSK-3 $\beta$ and accumulation of cytosolic $\beta$-catenin. The accumulated $\beta$-catenin then translocates into the nucleus where it binds TCF/LEF transcription factors to activate transcription of Wnt-responsive genes involved in cell proliferation and differentiation [35]. In the absence of Wnt activation, $\beta$-catenin is constantly degraded by the proteasome employed by $\beta$-catenin phosphorylation, which occurs in a complex consisting of tumor suppressor proteins adenomatous polyposis coli (APC), Axin, and GSK-3 [36, 37]. Our results showed that the increase of Wnt elevated the mRNA and protein levels of $\beta$-catenin whereas Dkk1 decreased them, which are consistent with previous studies that Dkk1 interacts with LRP6 to prevent the formation of the LRP5/6Wnt-FZD complex [38]. Additionally, Dkk1 and FH535, a synthetic inhibitor of the canonical Wnt signaling pathway, completely abolished the effects of naringin on promoting $\beta$-catenin expression. Since Dkk1 inhibits Wnt signaling via LRP6 and FH535, which was proposed to stabilize Axin to facilitate $\beta$-catenin degradation, it can be implied that naringin may be involved in enhancing Wnt activation or blocking Axin function.

Under normal circumstances, the phosphorylation of $\beta$-catenin at residues 37 and 33 , which results in its rapid degradation by proteasome, is the key step in turning off Wnt signaling [39]. The unphosphorylated residues 41,37 and 33 of $\beta$-catenin are recently reported to be specifically mediated in Wnt signaling, and the phosphorylation of these residues may promote nuclear export $[40,41]$. However, $\beta$-catenin can also be activated by growth factors such as insulin-like growth factor-1 and insulin [42, 43]. Insulin phosphorylates GSK3 through phosphatidylinositol 3-kinase-activated Akt, leading to the inactivation of GSK3 and augmentation of $\beta$-catenin to induce glycogen synthase (GS) [44-46]. Akt stimulates cell proliferation and also phosphorylates $\beta$-catenin at Ser552 residue [47]. Instead of degradation, this phosphorylation of $\beta$-catenin increases its stabilization and transcriptional activity $[47,48]$. It was reported that AMPK may also be involved in stabilizing $\beta$-catenin by phosphorylating Ser552 [49]. We found that phosphorylation at Ser552 on $\beta$-catenin was significantly promoted by naringin treatment, which in turn activatedTCF/LEF transcription factors. Akti-1/2 is an allosteric inhibitor of Akt1 and 2 and dorsomorphin is a potent and reversible ATP-competitive inhibitor of AMPK [50,51]. Interestingly, the additions of Akti$1 / 2$ or dorsomorphin in UMR-106 cells treated by naringin partially reduced the effects of naringin on activating $\beta$-catenin, suggesting that naringin may participate in the regulation of $\beta$-catenin via promoting AMPK and Akt to stabilize $\beta$-catenin and inactivate GSK-3. It was reported that dorsomorphin could also inhibit BMP signaling through the SMAD pathway, likely by affecting BMPR-I kinase activity [52]. It is possible that naringin may also facilitate BMP signaling, which needs to be further investigated. The translocation of $\beta$-catenin into the nucleus by naringin treatment could be caused by the accumulation of activated 
$\beta$-catenin in cytoplasm, since Akti-1/2 and dorsomorphin treatment reduced $\beta$-catenin in the nucleus. However, the mechanism of $\beta$-catenin translocation from cytoplasm into the nucleus remains unclear, and it will be interesting to examine whether naringin plays a role in $\beta$-catenin translocation as well.

We demonstrated that naringin exerted a function to increase bone development in vivo. It significantly improved the bone quality in an OVX mouse model, which mimicks postmenopausal women lack of estrogen. RANKL, which is necessary for osteoclast differentiation, is inhibited by decoy receptor osteoprotegerin (OPG) [53]. Estrogens favoring OPG but suppressing RANKL expressions in osteoblasts mainly attributes to bone formation. Parathyroid hormone (PTH) has been employed in treating bone loss in postmenopausal women by reducing RANKL and increasing OPG. ALP expression level is related to osteoblast and can be controlled by BMP-2 [8]. However, this induction of ALP partly relies on Wnt signaling. We have demonstrated here that naringin may not be a part of inducing Wnt proteins. Hence, the action of naringin is possibly linked to BMP signaling. Based on our study, ALP activity and cell proliferation were significantly improved by both naringin and PTH treatment, indicating that naringin functions in not only stabilizing $\beta$-catenin but also inducing BMP signaling and Akt promoted cell proliferation.

Previous study found that the activation of AMPK could induce the expression of BMP2 to gain bone mass and improve bone quality [54]. BMP-2 is an osteogenic factor, which synergizes with $\beta$-catenin to direct osteogenic lineage allocation and contribute to new bone formation [55]. BMP-2 was previously reported to play an important role in osteogenic differentiation of vascular smooth muscle cells via Wnt/ $\beta$-catenin signaling pathway, suggesting an underlying mechanism linking function of naringin with BMP- 2 and Wnt/ $\beta$ catenin in osteogenesis [56]. Additionally, the AMPK inhibitor dorsomorphin in this study exhibited a negative impact on naringin function, suggesting naringin may promote AMPK to stabilize $\beta$-catenin and in turn activate BMP signaling. The activation of BMP-2 by naringin via Akt in osteoblasts was also documented [28]. Taken together, the protective function of naringin in bone development by stabilizing $\beta$-catenin through AMPK and Akt signaling can be implied in the present study.

\section{Conclusion}

In conclusion, our study highlights a new finding on the mechanism of naringin functions in bone development. Actions of naringin involve the recruitments of AMPK and Akt signaling. We confirmed in this study that naringin treatment exerts protective role in bone development, which is consistent with other studies. Our results suggest that naringin facilitates phosphorylation of $\beta$-catenin at Ser552 residues which stabilizes $\beta$-catenin and leads to the translocation of $\beta$-catenin into the nucleus. The functional relationship between naringin and AMPK and Akt should be taken into consideration for the understanding of the mechanical pathway of naringin. Finally our current study supports the role of naringin as a potential therapeutic agent in treating osteoporosis.

\section{Acknowledgements}

This work was supported by National Natural Science Foundation of China (81201392, 81202307, 81201144), Natural Science Foundation of Shandong Province (ZR2012HQ025).

\section{Disclosure Statement}

The authors declare that there are no conflicts of interest. 


\section{Cellular Physiology Cell Physiol Biochem 2015;36:1563-1576 \begin{tabular}{l|l|l} 
DOI: 10.1159/000430319 & (C) 2015 S. Karger AG, Basel
\end{tabular} \begin{tabular}{l|l|l|l|l|l} 
and Biochemistry Published online: July 10, 2015 & www.karger.com/cpb \\
\cline { 1 - 2 }
\end{tabular} \\ Wang et al.: Mechanism of Naringin on Facilitating Bone Formation}

\section{References}

$1 \quad$ Riggs BL, Melton LJ, 3rd: Involutional osteoporosis. N Engl J Med 1986;314:1676-1686.

2 Riggs BL, Melton LJ, 3rd: The worldwide problem of osteoporosis: Insights afforded by epidemiology. Bone 1995; 17:505S-511S.

3 Assessment of fracture risk and its application to screening for postmenopausal osteoporosis. Report of a who study group. World Health Organ Tech Rep Ser 1994;843:1-129.

4 Kanis JA, Melton LJ, 3rd, Christiansen C, Johnston CC, Khaltaev N: The diagnosis of osteoporosis. J Bone Miner Res 1994;9:1137-1141.

5 Cummings SR, Kelsey JL, Nevitt MC, O'Dowd KJ: Epidemiology of osteoporosis and osteoporotic fractures. Epidemiol Rev 1985;7:178-208.

6 Kanis JA: Diagnosis of osteoporosis and assessment of fracture risk. Lancet 2002;359:1929-1936.

7 Bain G, Muller T, Wang X, Papkoff J: Activated beta-catenin induces osteoblast differentiation of c3h10t1/2 cells and participates in bmp2 mediated signal transduction. Biochem Biophys Res Commun 2003;301:8491.

8 Rawadi G, Vayssiere B, Dunn F, Baron R, Roman-Roman S: Bmp-2 controls alkaline phosphatase expression and osteoblast mineralization by a wnt autocrine loop. J Bone Miner Res 2003;18:1842-1853.

9 Hartmann C, Tabin CJ: Dual roles of wnt signaling during chondrogenesis in the chicken limb. Development 2000;127:3141-3159.

10 Chen Y, Chen L, Yin Q, Gao H, Dong P, Zhang X, Kang J: Reciprocal interferences of tnf-alpha and wnt1/ beta-catenin signaling axes shift bone marrow-derived stem cells towards osteoblast lineage after ethanol exposure. Cell Physiol Biochem 2013;32:755-765.

11 Moon RT, Bowerman B, Boutros M, Perrimon N: The promise and perils of wnt signaling through betacatenin. Science 2002;296:1644-1646.

12 Ruel L, Stambolic V, Ali A, Manoukian AS, Woodgett JR: Regulation of the protein kinase activity of shaggy(zeste-white3) by components of the wingless pathway in drosophila cells and embryos. J Biol Chem 1999;274:21790-21796.

13 Tamai K, Semenov M, Kato Y, Spokony R, Liu C, Katsuyama Y, Hess F, Saint-Jeannet JP, He X: Ldl-receptorrelated proteins in wnt signal transduction. Nature 2000;407:530-535.

14 Bienz M, Clevers H: Armadillo/beta-catenin signals in the nucleus--proof beyond a reasonable doubt? Nat Cell Biol 2003;5:179-182.

15 Kahler RA, Westendorf JJ: Lymphoid enhancer factor-1 and beta-catenin inhibit runx2-dependent transcriptional activation of the osteocalcin promoter. J Biol Chem 2003;278:11937-11944.

16 Boyle WJ, Simonet WS, Lacey DL: Osteoclast differentiation and activation. Nature 2003;423:337-342.

17 Jilka RL, Hangoc G, Girasole G, Passeri G, Williams DC, Abrams JS, Boyce B, Broxmeyer H, Manolagas SC: Increased osteoclast development after estrogen loss: Mediation by interleukin-6. Science 1992;257:88-91.

18 Mizuno A, Amizuka N, Irie K, Murakami A, Fujise N, Kanno T, Sato Y, Nakagawa N, Yasuda H, Mochizuki S, Gomibuchi T, Yano K, Shima N, Washida N, Tsuda E, Morinaga T, Higashio K, Ozawa H: Severe osteoporosis in mice lacking osteoclastogenesis inhibitory factor/osteoprotegerin. Biochem Biophys Res Commun 1998;247:610-615.

19 Mizuno A, Kanno T, Hoshi M, Shibata O, Yano K, Fujise N, Kinosaki M, Yamaguchi K, Tsuda E, Murakami A, Yasuda H, Higashio K: Transgenic mice overexpressing soluble osteoclast differentiation factor (sodf) exhibit severe osteoporosis. J Bone Miner Metab 2002;20:337-344.

20 Lu Y, Zhang C, Bucheli P, Wei D: Citrus flavonoids in fruit and traditional chinese medicinal food ingredients in china. Plant Foods Hum Nutr 2006;61:57-65.

21 Deyhim F, Mandadi K, Faraji B, Patil BS: Grapefruit juice modulates bone quality in rats. J Med Food 2008;11:99-104.

22 Zhang P, Dai KR, Yan SG, Yan WQ Zhang C, Chen DQ, Xu B, Xu ZW: Effects of naringin on the proliferation and osteogenic differentiation of human bone mesenchymal stem cell. Eur J Pharmacol 2009;607:1-5.

23 Li N, Jiang Y, Wooley PH, Xu Z, Yang SY: Naringin promotes osteoblast differentiation and effectively reverses ovariectomy-associated osteoporosis. J Orthop Sci 2013;18:478-485.

24 Ang ES, Yang X, Chen H, Liu Q, Zheng MH, Xu J: Naringin abrogates osteoclastogenesis and bone resorption via the inhibition of rankl-induced nf-kappab and erk activation. FEBS Lett 2011;585:2755-2762. 


\section{Cellular Physiology Cell Physiol Biochem 2015;36:1563-1576 \begin{tabular}{l|l|l}
\hline DOI: 10.1159/000430319 & (C) 2015 S. Karger AG, Basel
\end{tabular} www.karger.com/cpb \\ Wang et al.: Mechanism of Naringin on Facilitating Bone Formation}

25 Ding S, Hu J, Yang J, Liu L, Huang W, Gu X, Ye Y, Huang L, Liang Y, Chen B, Zhuge Q: The inactivation of jak2/stat3 signaling and desensitization of $\mathrm{m} 1 \mathrm{mach}$ in minimal hepatic encephalopathy (mhe) and the protection of naringin against mhe. Cell Physiol Biochem 2014;34:1933-1950.

26 Pang WY, Wang XL, Mok SK, Lai WP, Chow HK, Leung PC, Yao XS, Wong MS: Naringin improves bone properties in ovariectomized mice and exerts oestrogen-like activities in rat osteoblast-like (umr-106) cells. Br J Pharmacol 2010;159:1693-1703.

27 Wong RW, Rabie AB: Effect of naringin on bone cells. J Orthop Res 2006;24:2045-2050.

28 Wu JB, Fong YC, Tsai HY, Chen YF, Tsuzuki M, Tang CH: Naringin-induced bone morphogenetic protein-2 expression via pi3k, akt, c-fos/c-jun and ap-1 pathway in osteoblasts. Eur J Pharmacol 2008;588:333-341.

29 Hodsman AB, Bauer DC, Dempster DW, Dian L, Hanley DA, Harris ST, Kendler DL, McClung MR, Miller PD, Olszynski WP, Orwoll E, Yuen CK: Parathyroid hormone and teriparatide for the treatment of osteoporosis: A review of the evidence and suggested guidelines for its use. Endocr Rev 2005;26:688-703.

30 Kwak HB, Kim JY, Kim KJ, Choi MK, Kim JJ, Kim KM, Shin YI, Lee MS, Kim HS, Kim JW, Chun CH, Cho HJ, Hong GY, Juhng SK, Yoon KH, Park BH, Bae JM, Han JK, Oh J: Risedronate directly inhibits osteoclast differentiation and inflammatory bone loss. Biol Pharm Bull 2009;32:1193-1198.

31 Kameda T, Mano H, Yuasa T, Mori Y, Miyazawa K, Shiokawa M, Nakamaru Y, Hiroi E, Hiura K, Kameda A, Yang NN, Hakeda Y, Kumegawa M: Estrogen inhibits bone resorption by directly inducing apoptosis of the bone-resorbing osteoclasts. J Exp Med 1997;186:489-495.

32 Xie F, Wu CF, Lai WP, Yang XJ, Cheung PY, Yao XS, Leung PC, Wong MS: The osteoprotective effect of herba epimedii (hep) extract in vivo and in vitro. Evid Based Complement Alternat Med 2005;2:353-361.

33 Gasser JA, Willnecker J: Bone measurements by peripheral quantitative computed tomography in rodents. Methods Mol Biol 2012;816:477-498.

34 Zhang Y, Leung PC, Che CT, Chow HK, Wu CF, Wong MS: Improvement of bone properties and enhancement of mineralization by ethanol extract of fructus ligustri lucidi. Br J Nutr 2008;99:494-502.

35 Krishnan V, Bryant HU, Macdougald OA: Regulation of bone mass by wnt signaling. J Clin Invest 2006;116:1202-1209.

36 Topol L, Jiang X, Choi H, Garrett-Beal L, Carolan PJ, Yang Y: Wnt-5a inhibits the canonical wnt pathway by promoting gsk-3-independent beta-catenin degradation. J Cell Biol 2003;162:899-908.

37 Behrens J, Jerchow BA, Wurtele M, Grimm J, Asbrand C, Wirtz R, Kuhl M, Wedlich D, Birchmeier W: Functional interaction of an axin homolog, conductin, with beta-catenin, apc, and gsk3beta. Science 1998;280:596-599.

38 Bafico A, Liu G, Yaniv A, Gazit A, Aaronson SA: Novel mechanism of wnt signalling inhibition mediated by dickkopf-1 interaction with lrp6/arrow. Nat Cell Biol 2001;3:683-686.

39 Hart M, Concordet JP, Lassot I, Albert I, del los Santos R, Durand H, Perret C, Rubinfeld B, Margottin F, Benarous R, Polakis P: The f-box protein beta-trcp associates with phosphorylated beta-catenin and regulates its activity in the cell. Curr Biol 1999;9:207-210.

40 Staal FJ, Noort Mv M, Strous GJ, Clevers HC: Wnt signals are transmitted through n-terminally dephosphorylated beta-catenin. EMBO Rep 2002;3:63-68.

41 Hendriksen J, Fagotto F, van der Velde H, van Schie M, Noordermeer J, Fornerod M: Ranbp3 enhances nuclear export of active (beta)-catenin independently of crm1. J Cell Biol 2005;171:785-797.

42 Playford MP, Bicknell D, Bodmer WF, Macaulay VM: Insulin-like growth factor 1 regulates the location, stability, and transcriptional activity of beta-catenin. Proc Natl Acad Sci U S A 2000;97:12103-12108.

43 Liu C, Li Y, Semenov M, Han C, Baeg GH, Tan Y, Zhang Z, Lin X, He X: Control of beta-catenin phosphorylation/degradation by a dual-kinase mechanism. Cell 2002;108:837-847.

44 Weston CR, Davis RJ: Signal transduction: Signaling specificity- a complex affair. Science 2001;292:24392440.

45 Harwood AJ: Regulation of gsk-3: A cellular multiprocessor. Cell 2001;105:821-824.

46 Frame S, Cohen P, Biondi RM: A common phosphate binding site explains the unique substrate specificity of gsk3 and its inactivation by phosphorylation. Mol Cell 2001;7:1321-1327.

47 Fang D, Hawke D, Zheng Y, Xia Y, Meisenhelder J, Nika H, Mills GB, Kobayashi R, Hunter T, Lu Z: Phosphorylation of beta-catenin by akt promotes beta-catenin transcriptional activity. J Biol Chem 2007;282:11221-11229. 


\section{Cellular Physiology Cell Physiol Biochem 2015;36:1563-1576 \begin{tabular}{ll|l} 
and Biochemistry & $\begin{array}{l}\text { DOI: 10.1159/000430319 } \\
\text { Published online: July 10, } 2015\end{array}$ & $\begin{array}{l}\text { O 2015 S. Karger AG, Basel } \\
\text { www.karger.com/cpb }\end{array}$ \\
\cline { 2 - 3 } &
\end{tabular} \\ Wang et al.: Mechanism of Naringin on Facilitating Bone Formation}

48 He XC, Zhang J, Tong WG, Tawfik O, Ross J, Scoville DH, Tian Q, Zeng X, He X, Wiedemann LM, Mishina Y, Li L: Bmp signaling inhibits intestinal stem cell self-renewal through suppression of wnt-beta-catenin signaling. Nat Genet 2004;36:1117-1121.

49 Zhao J, Yue W, Zhu MJ, Sreejayan N, Du M: Amp-activated protein kinase (ampk) cross-talks with canonical wnt signaling via phosphorylation of $\beta$-catenin at ser 552. Biochem Biophys Res Comm 2010;395:146-151.

50 Gao Y, Zhou Y, Xu A, Wu D: Effects of an amp-activated protein kinase inhibitor, compound c, on adipogenic differentiation of 3t3-11 cells. Biol Pharm Bull 2008;31:1716-1722.

51 Gilot D, Giudicelli F, Lagadic-Gossmann D, Fardel 0: Akti-1/2, an allosteric inhibitor of akt 1 and 2, efficiently inhibits camkialpha activity and aryl hydrocarbon receptor pathway. Chem Biol Interact 2010;188:546-552.

52 Anderson GJ, Darshan D: Small-molecule dissection of bmp signaling. Nat Chem Biol 2008;4:15-16.

53 Khosla S: Minireview: The opg/rankl/rank system. Endocrinology 2001;142:5050-5055.

54 Kanazawa I, Yamaguchi T, Yano S, Yamauchi M, Sugimoto T: Activation of amp kinase and inhibition of rho kinase induce the mineralization of osteoblastic mc3t3-e1 cells through endothelial nos and bmp-2 expression. Am J Physiol Endocrinol Metab 2009;296:E139-146.

55 Mbalaviele G, Sheikh S, Stains JP, Salazar VS, Cheng SL, Chen D, Civitelli R: Beta-catenin and bmp-2 synergize to promote osteoblast differentiation and new bone formation. J Cell Biochem 2005;94:403-418.

56 Rong S, Zhao X, Jin X, Zhang Z, Chen L, Zhu Y, Yuan W: Vascular calcification in chronic kidney disease is induced by bone morphogenetic protein- 2 via a mechanism involving the wnt/ $\beta$-catenin pathway. Cell Physiol Biochem 2014;34:2049-2060. 